\title{
Development of Digital Intelligence Among Participants of Inclusive Educational Process
}

\section{Desarrollo de inteligencia digital entre los participantes del proceso educativo inclusivo}

\section{Olga Vladimirovna Solovieva*}

Federal State Autonomous Educational Institution of Higher Education "North Caucasus

Federal University", Stavropol, Russia

ORCID: https://orcid.org/0000-0003-4210-3334

\section{Nadezhda Andreevna Palieva}

Federal State Autonomous Educational Institution of Higher Education "North Caucasus

Federal University", Stavropol, Russia

ORCID: https://orcid.org/0000-0003-0886-2636

Natalia Mikhaylovna Borozinets

Federal State Autonomous Educational Institution of Higher Education "North Caucasus

Federal University", Stavropol, Russia

ORCID: https://orcid.org/0000-0003-1167-7132

Galina Yuryevna Kozlovskaya

Federal State Autonomous Educational Institution of Higher Education "North Caucasus

Federal University", Stavropol, Russia

ORCID: https://orcid.org/0000-0002-9445-9183

Julia Vladimirovna Prilepko

Federal State Autonomous Educational Institution of Higher Education "North Caucasus

Federal University", Stavropol, Russia

ORCID: https://orcid.org/0000-0003-2980-0303

Received 02-12-20 Revised 03-13-20 Accepted 07-13-20 On line 08-29-20

*Correspondence

Email: solovieva.o.v@bk.ru
Cite as:

Solovieva, O.V., Palieva, N.A., Borozinets, N.M., Kozlovskaya, G.Y., Prilepko, J.V. (2020). Development of Digital Intelligence Among Participants of Inclusive Educational Process. Propósitos y Representaciones, 8 (SPE2), e675. Doi: http://dx.doi.org/10.20511/pyr2020.v8nSPE2.675 


\section{Summary}

The article analyzes the problem of the development of digital intelligence among participants of inclusive educational process in the context of the global digitalization of modern society. The level of development of this problem is described. A brief analytical review of scientific research of digital educational environments and digitalization of education is presented. The features and advantages of this innovative approach are demonstrated. The risks for the mental and personal development of students in the transition of modern education to digital format are listed. The results of a pilot research of the development of the main components of digital intelligence among participants in an inclusive educational process (teachers, students and their parents) are presented. A model of the targeted development of digital intelligence in the practice of an inclusive educational organization is proposed.

Keywords: Digital Intelligence; Digital Educational Environment; Advantages and Risks of Digitalization of Education; Inclusive Educational Process; Students with Disabilities.

\section{Resumen}

El artículo analiza el problema del desarrollo de la inteligencia digital entre los participantes del proceso educativo inclusivo en el contexto de la digitalización global de la sociedad moderna. Se describe el nivel de desarrollo de este problema. Se presenta una breve revisión analítica de la investigación científica de los entornos educativos digitales y la digitalización de la educación. Se demuestran las características y ventajas de este enfoque innovador. Se enumeran los riesgos para el desarrollo mental y personal de los estudiantes en la transición de la educación moderna al formato digital. Se presentan los resultados de una investigación piloto del desarrollo de los principales componentes de la inteligencia digital entre los participantes en un proceso educativo inclusivo (docentes, estudiantes y sus padres). Se propone un modelo del desarrollo dirigido de la inteligencia digital en la práctica de una organización educativa inclusiva.

Palabras clave: Inteligencia digital; Entorno educativo digital; Ventajas y Riesgos de la Digitalización de la Educación; Proceso educativo inclusive; Estudiantes con Discapacidad.

\section{Introduction}

In conditions of inclusive education, the participants of which are both conditionally healthy people and people with disabilities, the use of digital information and communication technologies is an urgent and vital task. Digital technologies significantly expand the boundaries of education for children who find it difficult to attend school due to their limitations. The Internet and the electronic environment as a whole are used not only to assist in the development of training programs, but also for effective online communication. This opens up new opportunities for people with disabilities, ensures the satisfaction of their social and educational needs, and helps in adaptation and socialization.

Despite all the advantages of global digitalization and the digital transformation of education, there are quite serious risks of the negative impact of this phenomenon on the psychological health of its participants. Including the risk of digital dependence, the risk of deformation of cognitive abilities and speech of students, the risk of developing informational mental pseudo-retardation (the pathological state of brain degradation under the influence of gadgets), the risk of digital autism, the risk of involvement in cyberbullying and other risks that are caused by excessive information and technological load and stay online. Therefore, close attention on the part of educators is necessary for preventive measures to prevent the negative consequences of an excessive digital attack on the psyche of children and their parents. 
One of the key tasks in solving this problem is the development of digital intelligence. Digital intelligence is a special ability that allows you to adapt to the requirements of digital life and withstand its challenges. It implies digital literacy, algorithmic, design and critical reasoning, developed analytical and creative abilities, the ability to make decisions in the face of uncertainty and an excess of information, the ability to build network communication and expand the capabilities of the virtual world. At the same time, digital intelligence involves developed selfcontrol, which ensures a healthy balance between online and offline life, the ability to understand cyber threats and use adequate means of protection against them.

Modern scientific research and practical observations show that modern educators, students and their parents do not have the proper level of development of digital intelligence. Therefore, a contradiction arises between the need for a sufficient level of digital intelligence for all participants in the inclusive educational process, as a guarantee of adaptability and maintaining psychological health in the modern world of digitalization and the lack of a system of measures aimed at its development. This contradiction explains the research problem, which consists in the need to develop scientifically based methods, means and conditions for the targeted formation of digital intelligence among participants in an inclusive educational process in order to counter possible threats to digitalization of education and preserve the psychological health of teachers and students.

The Research Purpose. To identify the level of development of the main components of digital intelligence among participants in the inclusive educational process (teachers, students and their parents) and to develop a model of its targeted development in the context of global digitalization of education.

\section{Research Methods}

To achieve such purpose, general scientific and psychological research methods were used. Theoretical: a review and analytical method for the research and analysis of the main approaches and concepts of digitalization of education and the development of digital intelligence. Experimental: diagnostic methods, survey and testing methods, methods of mathematical and statistical analysis of experimental data. The following techniques were used in the research: a test to assess the critical reasoning of students (I. Ilyasov, Yu.Gushchin); questionnaire of emotional intelligence D. Lusin; questionnaire "The style of self-regulation of behavior" (V. Morosanova). The survey respondents were educators, students and their parents. The place of the research is secondary school № 21 of Stavropol. The total amount of research participants was 45 persons. The sample is random, randomized. The research was conducted from November to December 2019. Methods and procedures for statistical data processing were carried out using the SPSS v package. 22.0 to prove the reliability of the conclusions (indicators of descriptive statistics, nonparametric statistics).

\section{Results}

A theoretical analysis of the main approaches and concepts of digitalization of education and the development of digital intelligence revealed the presence of a significant amount of studies devoted to this problem. The most widely represented problem is constructive electronic communication and the development of network technologies in education (Rubinstein, Meyer, Evans, 2001). The best e-learning practices are described (Best practices of e-learning: a collection of materials of the II Methodical Conference, 2016).

I. Blinov, M. Dulinov, E. Yesenina, I. Sergeev studies devoted to the research of the resources of the digital educational environment. These authors work out didactic concept of digital vocational education and training (Blinov et al., 2019). 
I. Avadayeva, S. Anisimova-Tkalich, E. Vezetiu, E. Vovk, V. Goldenova, V. Grebennikova, A. Kovtanyuk, K. Krechetnikov, E. Mantaeva, L. Mironov, L. Orlova, I. Slobodchikova, A. Tkalich, V. Chernyavskaya, M. Sher in a collective monograph proposed methodological foundations for the formation of a modern digital educational environment (Medvedeva, Kroshilin, 2013).

N. Ignatova revealed axiological and pedagogical problems of education in the digital age (Ignatova, 2017). The author described the conditions of the virtual educational environment as a way of developing social capital (Ignatova, 2011).

So, analytical research of this problem revealed the high relevance and importance for the modern world of issues related to the digitalization of education.

In our understanding, the digital educational environment is an open set of information systems designed to provide various tasks of the educational process. The digitalization of the educational process is considered as an innovative phenomenon of modern education. It implies a system of effective and comfortable provision of information and communication services to students and has a beneficial effect on the modernization of the educational process, helps students develop learning skills in the digital world, the ability to create digital projects for their future profession (Blinov et al., 2019; Medvedeva, Kroshilin, 2013).

Along with the advantages of digitalization of education, it should be noted that the digital educational environment as a main changes the ontology of education, since the space and time of the human life world are changing. Changes are observed at the level of perception of the deep foundation of time, manifested in desynchronization of processes in real and virtual reality (Ignatova, 2017).

There is a gap between the high-speed flow of information in the remote education sector and the slow passage of time in the traditional educational process. In the context of digitalization, education becomes a plural, nonequilibrium system with such characteristics as variability, genericity and fundamental "complexity" of internal processes, the existence of which is determined by network logic (Ignatova, 2017). The widespread use of IT-technologies and Webpractices can become a real threat to traditional education (Toffler, Toffler, 2008). In this regard, focused managerial efforts are required to maintain an optimal balance between the sectors of virtual and real education.

Of particular importance is the solution to the problem of the influence of digital technologies on the psyche of participants of the digital educational environment. First of all, on personal and intellectual development, as well as educational achievements of students (Volojanina, Lokhaneva, 2018; Solovieva, 2013). Many foreign studies indicate that in the context of digital learning, students experience "informational and cognitive overload", "background multitasking", "interruption and switching attention" (Kirsch, 2000). A number of scientific studies discuss the risks of cognitive abilities and speech of students, leading to a pathological state of brain degradation, called "information mental pseudo-retardation". Also of particular concern are the risks of digital autism, involvement in cyberbullying, and other risks associated with workload of information technology and long network stays (Solovieva, Kokorova, 2020).

In order to prevent the negative impact of excessive digital attacks on the psyche of children and their parents, it is necessary to prevent threats that have serious consequences for the psychological health of the younger generation. In connection with the need to solve this problem, let us turn to the phenomenon of "digital intelligence", which is new for science and practice. This type of intelligence determines the effectiveness of man in the modern world. 
Despite the widespread representation of foreign and domestic studies on the impact of digitalization of education on the personality of students, there are practically no studies on the research of digital intelligence. This situation necessitates a thorough research of this phenomenon, which includes digital literacy, algorithmic, design, critical and reflective reasoning, developed analytical and creative abilities, the ability to make decisions in the face of uncertainty and an excess of information. The capabilities of digital intelligence contribute to the effective building of network communication and the expansion of the capabilities of the virtual world. But the main advantage of digital intelligence is a person's high self-control, ensuring a healthy balance between online and offline life, as well as the ability to intelligently and constructively manage the content of his life using adequate means of protection against cyber threats. Thus, digital intelligence is a set of cognitive, social and emotional abilities that allow people to confront challenges and adapt to the requirements of digital life (E-education: prospects for the use of SMART-technologies, 2016).

In our opinion, the structural components of digital intelligence are high critical reasoning and the ability to reflect; the ability to communicate effectively, involving the ability to build and maintain social contacts (which in turn implies a high emotional intelligence); a high degree of self-regulation, ensuring the success of activities due to the conscious advancement of goals and management of their achievement. Based on multiple studies, we believe that today in society there is an urgent need for reflection and critical reasoning of its citizens (Avadayeva et al., 2018). Critical reasoning is a combination of qualities and skills that determine a high level of research culture in teaching activities. The insufficient criticality of a person's thinking exposes him to negative media influence, blocking his own assessment of phenomena and events.

I. Zagashev notes that a person with a high level of critical reasoning is able to correctly build reasoning, make inferences, prove his arguments and evaluate the arguments of other people. He has various methods of interpreting and evaluating information, he is able to highlight contradictions and types of structures present in the text, to argue his point of view, relying not only on logic, but also on the interlocutor's ideas. It is important to emphasize that a critically thinking person knows how to effectively interact with information spaces, accepts the multipolarity of the world around him and the possibility of the coexistence of various points of view within the framework of universal values. Critical reasoning is associated with evaluative, reflective reasoning, for which knowledge is not the end, but the starting point and is based on personal experience and verified facts (Zagashev, Zaire-Bek, 2003).

In order to assess the level of development of the identified structural components of digital intelligence, a pilot research was organized in secondary school. The respondents to the research are teachers, 9th grade students and parents amount 45 persons (15 persons from each category). Among the students were three teenagers with disabilities. To assess critical reasoning the test of I. Ilyasov and Y. Gushchin was used (n.d.). Despite that this test was designed for students in grades 9 th, we used it for all. The rationale for this is that by the age of 14-15, a person has formed a theoretical (L. Vygotsky) and hypothetical-deductive reasoning (J. Piaget) as the last stage in the development of intelligence.

During testing, we assess the following types of skills:

- ability to make logical conclusions and substantiate answer;

- ability to evaluate sequences of conclusions;

- the ability to analyze and draw conclusions about the causes of phenomena;

- ability to analyze and evaluate the content of texts;

- ability to detect errors associated with the uncertainty and ambiguity of expressions and terms; 
- the ability to detect relevant (significant in this case) information against the background of it excess.

Testing data is presented in table 1 and figure 1.

Table 1.

Indicators of the development of critical reasoning and reflection among participants of an inclusive educational process

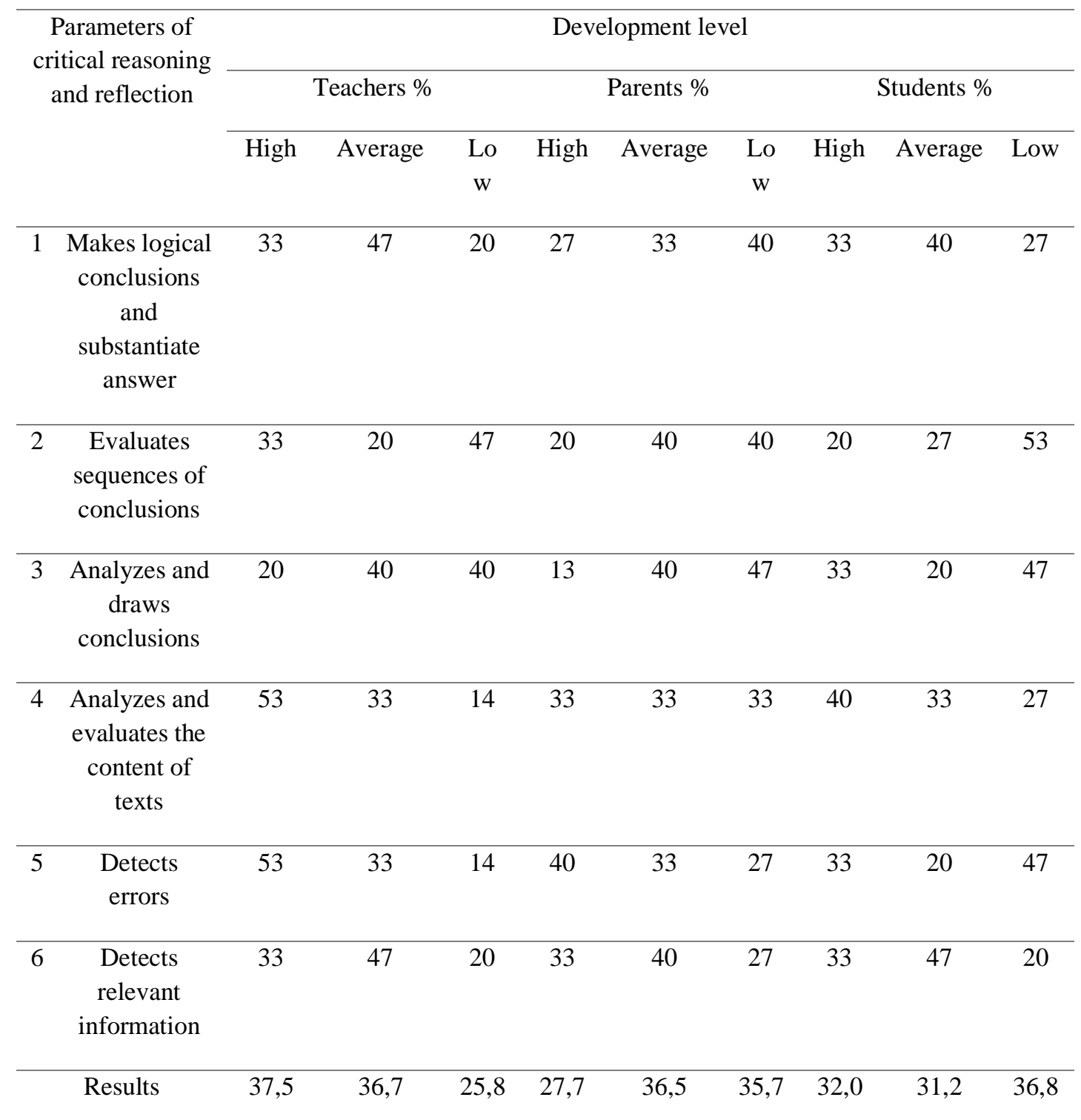




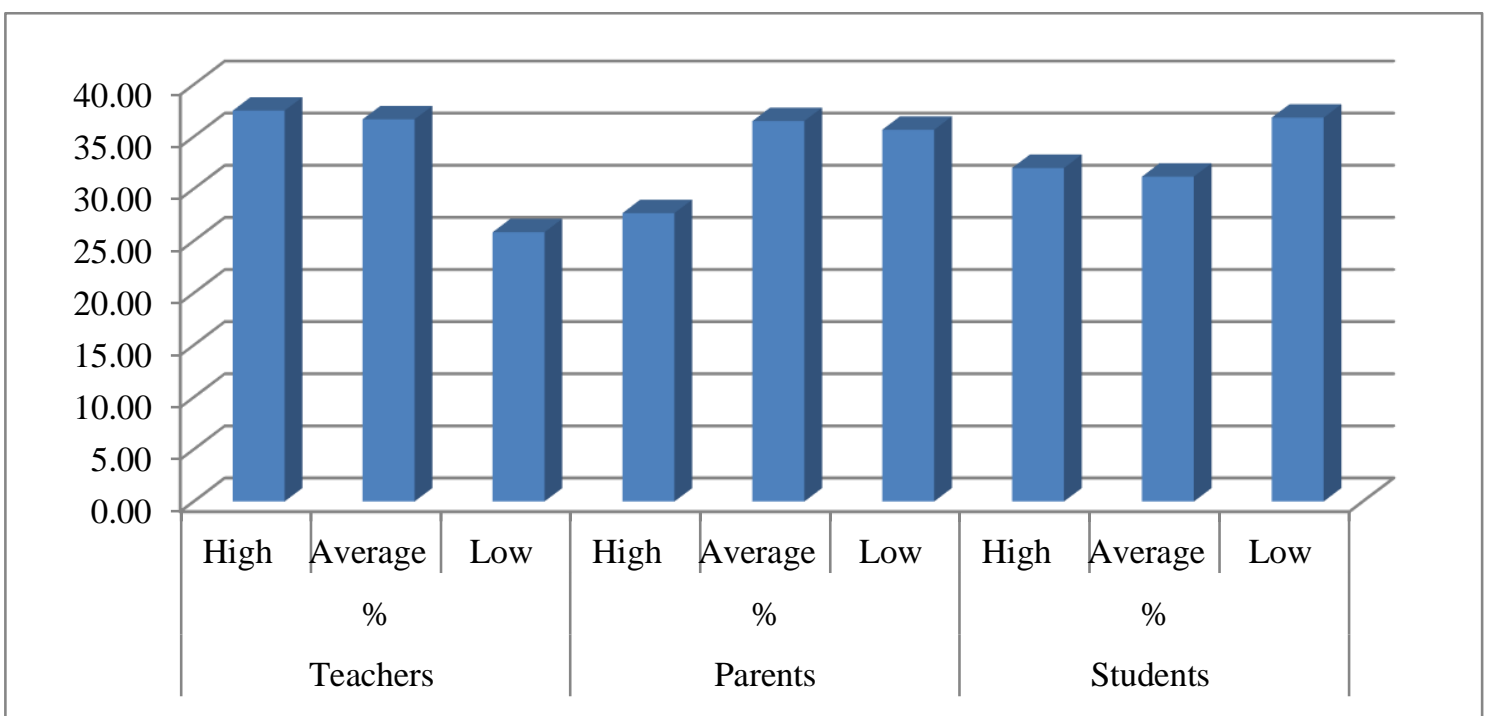

Figure 1. Indicators of the development of critical reasoning and reflection

In order to identify the significance of differences between the two samples - teachers and students, the values of the results were ranked from maximum to minimum and the U-MannWhitney criterion was calculated to assess the differences between two independent samples by the level of quantitative characteristics. We did mathematical statistics in the computer program SPSS v. 23.0. The results are presented in table 2.

Table 2.

Results of the comparison two samples (teachers and students) on parameters of critical reasoning and reflection

\begin{tabular}{ccccccc}
\hline Parameter & 1 & 2 & 3 & 4 & 5 & 6 \\
\hline U- criterion & 179.0 & 712.0 & 1324.0 & 361.0 & 1619.0 & 752.0 \\
\hline $\begin{array}{c}\mathrm{p} \\
\begin{array}{c}\text { significance } \\
\text { level })\end{array}\end{array}$ & $.000^{* *}$ & $.033^{*}$ & .181 & $.017^{*}$ & .397 & $.034^{*}$ \\
& & & & & &
\end{tabular}

$\mathrm{p}^{*}$ - significance of differences level $\mathrm{p}<0.05 ; \mathrm{p}^{* *}$ - significance of differences level $\mathrm{p}<0.01$

It can be seen from the results that in the "teachers" group the total result for all types of skills exceeds the results of the "parents" and "students" group. High level was found in $37.5 \%$ of teachers, an average in $36.7 \%$, and a low in $25.8 \%$.

Thus, it can be seen that in the group of teachers, predominantly high and average levels of critical reasoning were identified.

The results of testing parents showed that only $27.7 \%$ of respondents showed a high level, $36.5 \%$ average, $35.7 \%$ low. In this case we state that in the group of parents, mainly average and low levels of critical reasoning were revealed.

Testing of students revealed that $32 \%$ have a high level of critical thinking, $31.2 \%$ have an average level and $36.8 \%$ have a low level. Based on these indicators, a predominantly low level was identified in the group of students. 
At the same time, if we compare these results with the indicators of the "parents" group, we find that the group of "students" exceeds them in terms of a high level (32.0\% compared with $27.7 \%)$.

Thus, the testing data of critical reasoning and reflection showed predominantly high and average levels among teachers, mostly middle and low levels among parents, and mostly low levels among students with a fairly high percentage of high rates.

In order to identify the level of development of emotional intelligence, we used the questionnaire of emotional intelligence D. Lusin. This technique involves identifying the degree of understanding of other people's emotions and managing them (InterEI - interpersonal emotional intelligence); understanding of their own emotions and their management (IntraEI - intrapersonal emotional intelligence); ability to understand one's and other's emotions (UE); ability to control one's and other's emotions (CE).

The technique contains the following subscales: OUE - under-standing of other's emotions - the ability to understand the emotional state of a person on the basis of external manifestations of emotions (facial expressions, gesticulation, sounding voice) and / or intuitively; sensitivity to the internal states of other people. OME - managing other's emotions - the ability to evoke certain emotions in other people, to reduce the intensity of unwanted emotions. Perhaps a penchant for manipulating people. SUE - understanding of self-emotions - ability to realize one's emotions: their recognition and identification, understanding of reasons, ability to verbal description. SME - management of self-emotions - the ability and need to control one's emotions, evoke and maintain desirable emotions and control unwanted ones. SCE - self-expression control - the ability to control the external manifestations of self-emotions. Diagnostic results are presented in table 3 and in figure 2 .

Table 3.

Indicators of the development of emotional intelligence in participants of an inclusive educational process

\begin{tabular}{|c|c|c|c|c|c|c|c|c|c|}
\hline \multirow{3}{*}{$\begin{array}{l}\text { Emotional } \\
\text { intelligence }\end{array}$} & \multicolumn{9}{|c|}{ Development level } \\
\hline & \multicolumn{3}{|c|}{ Teachers \% } & \multicolumn{3}{|c|}{ Parents $\%$} & \multicolumn{3}{|c|}{ Students $\%$} \\
\hline & High & Average & Low & High & Average & Low & High & Average & Low \\
\hline $\begin{array}{c}\text { InterEI = } \\
\text { OUE + OME }\end{array}$ & 40 & 33 & 26 & 33 & 40 & 27 & 20 & 33 & 53 \\
\hline $\begin{array}{c}\text { IntraEI = } \\
\text { SUE + SME } \\
+ \text { SCE }\end{array}$ & 53 & 33 & 14 & 40 & 47 & 13 & 33 & 40 & 27 \\
\hline IIGEI & 46,5 & 33 & 20 & 36,5 & 43,5 & 20 & 26,5 & 36,5 & 40 \\
\hline
\end{tabular}




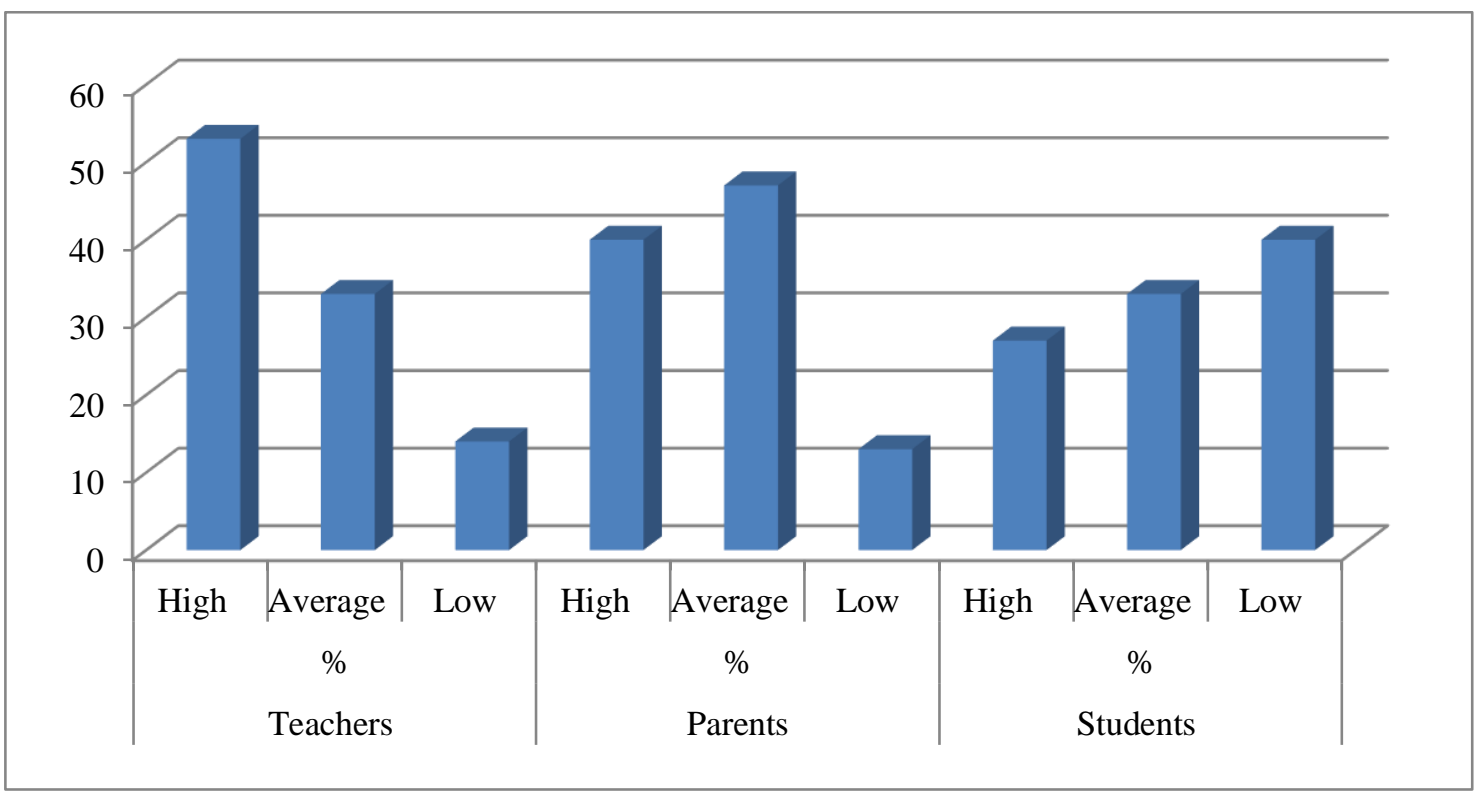

Figure 2. Integral indicators of general emotional intelligence

Table 4.

Results of the comparison two samples (teachers and students) on parameters of emotional intelligence

\begin{tabular}{ccccc}
\hline Parameter & InterEI & IntraEI & UE & CE \\
\hline U-criterion & 317.0 & 393.0 & 1324.0 & 523.5 \\
\hline $\mathrm{p}$ (significance level) & $.009^{* *}$ & $.019^{*}$ & .181 & $.024^{*}$ \\
\hline
\end{tabular}

$\mathrm{p}^{*}$ - significance of differences level $\mathrm{p}<0.05 ; \mathrm{p}^{* *}$ - significance of differences level $\mathrm{p}<0.01$

From the table 4 and diagram 2 it follows that almost half of the teachers who took part in the testing revealed a predominantly high level of emotional intelligence $(46.5 \%)$. This indicates the ability to understand and manage their emotions and those of others. We draw attention to the fact that the integral indicator of the overall emotional consists of the parameters of understanding other's emotions (OUE) and managing other's emotions (OME) and understanding self-emotions (SUE) and managing self-emotions (SME). According to our research, teachers are better guided in understanding and managing self-emotions. $33 \%$ of teachers demonstrated average level of emotional intelligence and $20 \%$ (3 persons) demonstrated a low level.

Most of the parents (43.5\%) demonstrated an average level of emotional intelligence. $35.5 \%$ have high and $20 \%$ have low.

Students demonstrated predominantly low and average levels of development of emotional intelligence. This is due to age-related features, lack of life experience and the limited variety of communications that are characteristic of modern adolescents. We draw attention to the fact that the number of respondents with a low level includes students with disabilities, which is explained by the scarcity of their personal development not fully compensated by the conditions of an inclusive environment. The significance of differences at the significance level is $p<0.05$ and $\mathrm{p}<0.01$ (U-criterion of Mann-Whitney). 
In order to identify the features of self-regulation of behavior, the questionnaire "Style of self-regulation of behavior" (V. Morosanova) was used. This technique allows you to identify the parameters of self-regulation on the following scales:

"Planning" characterizes the individual characteristics of the promotion and retention of goals, the formation of a person's conscious planning of activities.

"Modeling" allows you to diagnose the individual development of ideas about external and internal significant conditions, the degree of their awareness, detail and adequacy.

"Programming" diagnoses the individual development of conscious programming by a person of his actions.

"Evaluation of the results" characterizes the individual development and adequacy of the assessment of the themselves and the results of their activities and behavior.

"Flexibility" diagnoses the level of formation of regulatory flexibility, that is, the ability to rebuild, make corrections to the self-regulation system when changing external and internal conditions.

"Independence" characterizes the development of regulatory autonomy.

The questionnaire as a whole works as a single scale - evaluation of general selfregulation of behavior (GSRB), which estimates the general level of formation of an individual system of conscious self-regulation of arbitrary human activity.

Table 5.

Indicators of the general level of self-regulation among participants of an inclusive educational process

\begin{tabular}{|c|c|c|c|c|c|c|c|c|c|}
\hline \multirow{3}{*}{$\begin{array}{l}\text { Self- } \\
\text { regulation }\end{array}$} & \multicolumn{9}{|c|}{ Development level } \\
\hline & \multicolumn{3}{|c|}{ Teachers $\%$} & \multicolumn{3}{|c|}{ Parents \% } & \multicolumn{3}{|c|}{ Students \% } \\
\hline & High & Average & Low & High & Average & Low & High & Average & Low \\
\hline GSRB & 53 & 33 & 14 & 40 & 47 & 13 & 27 & 33 & 40 \\
\hline
\end{tabular}

GSRB - general self-regulation of behavior 


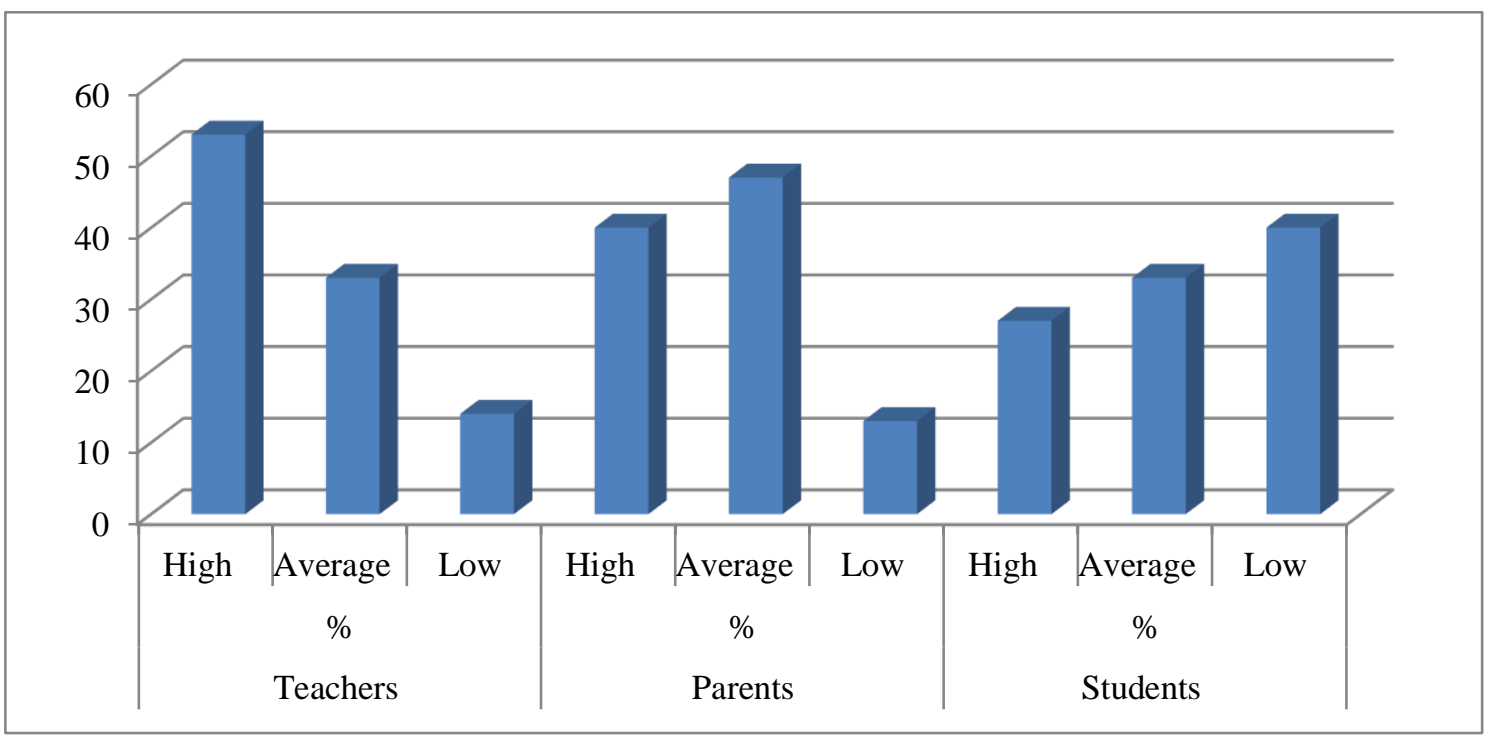

Figure 3. General development level of self-regulation

Based on the diagnostic results presented in the table 5 and in the diagram 3, it is seen that $50.3 \%$ of teachers demonstrated high level of self-regulation, $33 \%$ have average level and $14 \%$ ( 2 persons) have low level. Of the individual parameters, the highest indicators are presented by their ability to planing, evaluate results and Independence.

Parents are dominated by an average level of self-regulation - 47\%; high level was found in $40 \%$ of respondents and in $13 \%$ - low level.

At students it was revealed that $40 \%$ had a low level of self-regulation; $33 \%$ - average leve and $27 \%$ high level. The significance of differences at $\mathrm{p}<0.05$ and $\mathrm{p}<0.01$ (U-criterion of Mann-Whitneyt).

These results confirm that self-regulation is an important subjective quality that determines the ability to plan, model and control activities that is worst developed among students, due to age-related characteristics and social conditions of the development of modern schoolchildren (table. 6).

Table 6.

Results of the comparison two samples (teachers and students) on parameters of self-regulation

\begin{tabular}{ccccccc}
\hline Parameter & Planning & Modeling & Programming & $\begin{array}{c}\text { Evaluation } \\
\text { of the } \\
\text { results }\end{array}$ & Flexibility & Independence \\
\hline U-criterion & 921.5 & 942.0 & 256.0 & 1435,5 & 2967.0 & 252.0 \\
\hline $\begin{array}{c}\mathrm{p} \\
\text { (significance } \\
\text { level })\end{array}$ & $.043^{*}$ & $.047^{*}$ & $.000^{* *}$ & .283 & .697 & $.000^{* *}$ \\
& & & & & & \\
\hline
\end{tabular}

$\mathrm{p}^{*}$ - significance of differences level $\mathrm{p}<0.05 ; \mathrm{p}^{* *}-$ significance of differences level $\mathrm{p}<0.01$

Thus, in the course of our research, it was revealed that teachers observed mainly high and average levels of critical reasoning and reflective abilities, emotional intelligence, and a general level of self-regulation. This is due to the personal and professional competencies and the 
culture of teachers. Parents revealed mainly an average level of development of the studied components, which is explained by the heterogeneity of the sample in terms of education and professional affiliation. At students (grades 9th) are dominated by an average and low level of all the studied parameters. Based on these data, it is possible to judge the underdevelopment of digital intelligence of students. In this connection, a model of its targeted development was work out.

The purpose of this model is to develop the ability of participants of an inclusive educational process to competently, intelligently and efficiently use digital technologies and tools for learning and life, confronting the challenges and threats of digitalization and maintaining psychological health.

Main tasks:

- development of the ability to think critically, isolate the necessary information from the stream, evaluate the adequacy of the source, carry out reflection;

- development of the ability to have social and interpersonal contacts through network interaction;

- development of skills in setting goals and planning activities, evaluating its effectiveness and timely adjustments.

This model is based on general psychological principles - systemicity, determinism, development, unity of consciousness and activity, activity.

The organization and content of the work involves the implementation of activities on the system development of various areas of digital intelligence:

- digital competence - critical and algorithmic digital reasoning, the ability to find, evaluate, use and create content, understand information, isolate it from the stream and evaluate the adequacy of the source, reflection - the ability to analyze products of one's own activity;

- digital consumption - the possibility of adequate and safe use of digital information for mental health, isolating and protecting oneself from "toxic" information (the ability to cope with multitasking); ability to counter the risks and threats of digitalization;

- digital emotional intelligence and digital empathy - the ability to make effective communication and cooperative relationships with other people online and offline, ability to show empathy for the needs and feelings of others;

- digital subjectivity - the ability to organize and plan activity in accordance with goal setting; management of time spent in front of the monitor screen and self-control to prevent information and network dependence; the ability to create and maintain a healthy personality both in the virtual world and offline.

The conditions for the implementation of this model are:

- implementation of psychological trainings (intellectual, personal, communicative) with sequentially complicated special didactic tasks, games and exercises;

- systematic use of various teaching methods (practical, visual, verbal, gaming) and ITtechnologies in different, including virtual environments;

- using an individual approach taking into account the educational needs of students with disabilities;

- organization of interpersonal interaction and communication skills in a group with peers and adults;

- comprehensive work of an interdisciplinary team of specialists. 
The results of this model suggest three levels of formation of the components of digital intelligence - low, average and high, expressed in the level of development of critical reasoning and reflection, emotional intelligence as the basis of communication and the level of selfregulation. The content of the proposed model and the technology for its implementation is being prepared for development and requires a thorough, painstaking and thought out system of efforts of an interdisciplinary team of specialists. This is the perspective of this research.

\section{Conclusion}

In conclusion, we note that one of the main tasks of modern education is to ensure the rational use of the resources of the digital educational environment and the development of digital intelligence among all its participants. In the near future, digital intelligence will become an integral quality of modern man. Therefore, it is necessary to purposefully develop it not only among students, but also their parents and teachers, which will allow adults to better understand the difficulties and dangers that children may face when they study online and prepare them to use digital technologies safely and responsibly. In solving these problems, a differentiated approach is required for students of different ages and different categories in an inclusive educational process, which requires further scientific and practical working-out and their verification.

\section{References}

Avadayeva, I.V., Anisimova-Tkalich, S.K., Vezetiu, E.V., Vovk, E.V., Goldenova, V.S., Grebennikova, V.M., Kovtanyuk, A.E., Krechetnikov, K.G., Mantaeva, E.I., Mironov, L.V., Orlova, L.V., Slobodchikova, I.V., Tkalich, A.I., Chernyavskaya, V.S., Sher, M.L. (2018). Methodological foundations of the formation of a modern digital educational environment: monograph. Nizhny Novgorod: NGO "Professional Science". Retrieved from: http://scipro.ru/conf/monographeeducation-1.pdf

Best practices of e-learning: a collection of materials of the II Methodical Conference. (2016). Tomsk State University. Retrieved from: https://ido.tsu.ru/elearningconf/conf2016.pdf

Blinov, V.I., Dulinov, M.V., Yesenina, E.Yu., Sergeev, I.S. (2019). Didactic concept of digital vocational education and training. Moscow.

E-education: prospects for the use of SMART-technologies. (2016). Materials of the III International scientific-practical video conferencing. Tyumen.

Gushchin, Yu.F., Ilyasov, I.I. (n.d.). Experience in developing a test for assessing critical reasoning of students: site. Retrieved from: http://psyhoinfo.ru/opyt-razrabotki-testaocenki-kriticheskogo-myshleniya-shkolnikov

Ignatova, N.Yu. (2011). The virtual educational environment and the development of social capital. Open and distance education, 3(43), 56-62.

Ignatova, N.Yu. (2017). Education in the digital age: a monograph. Nizhny Tagil.

Kirsch, D. (2000). Few Thoughts on Cognitive Overload. Intellectica, 1(30), 19-51. Retrieved from: http://adrenaline.ucsd.edu/kirsh/Articles/Overload/Cognitive_Overload.pdf

Medvedeva, E.I., Kroshilin, S.V. (2013). Negative aspects of informatization of society. Economic journal, 5(41).

Rubinstein, J., Meyer, D., Evans, J. (2001). Executive Control of Cognitive Processes in Task switching. Journal of Experimental Psychology: Human Perception and Performance, 27(4), 763-797.

Solovieva, O.V. (2013). Phenomenology of the development of cognitive abilities of students. Modern problems of science and education, 3. Retrieved from: www.scienceeducation.ru/109-8835

Solovieva, O.V., Kokorova, S.D. (2020). Risks and positive aspects of the impact of the digital educational environment on the cognitive abilities of elementary school students. Applied 
Psychology and Psychoanalysis: electron. Science Magazine, 1. Retrieved from: http://ppip.idnk.ru

Toffler, E., Toffler, H. (2008). Revolutionary wealth. Moscow School of Digital Intelli-gence. Retrieved from: http://dq-int.tilda.ws/

Volojanina, S.S., Lokhaneva, K.V. (2018). The influence of information technology on the development of cognitive activity of children. The childhood, adolescence and youth in a context of scientific knowledge: materials of the VIII international scientific conference. Prague: Vědecko vydavatelské centrum «Sociosféra-CZ». Retrieved from: http://sisv.com/publ/vlijanie_informacionnykh_tekhnologij/6-1-0-641

Zagashev, I.O., Zaire-Bek, S.I. (2003). Critical reasoning: Technology Development. St. Petersburg. 